ECOLOGICA, Vol. 28, No 103 (2021), 363-368

https://doi.org/10.18485/ecologica.2021.28.103.5

Originalni naučni rad

UDC: $502.131 .1: 34$

502.174:34

\title{
Biotehnološki inženjering i zaštita životne sredine: pravni pristup
}

\section{Biotechnological engineering and environmental protection: legal approach}

\author{
Prof. dr Vladan Joldžić \\ Institut za kriminološka i sociološka istraživanja, Graćanička 18, Beograd, Srbija / \\ Institute for Criminological and Sociological Research, Graćanička 18, Belgrade, Serbia \\ e-mail: joldzicvladan2@gmail.com; vladanj@eunet.rs \\ Rad primljen / Received: 15.12.2020, Rad prihvaćen / Accepted: 10.08.2021.
}

\begin{abstract}
Sažetak: Rad je posvećen sagledavanju uticaja biotehnološkog inženjeringa, kako pozitivnog tako i negativnog, iz ugla prava. U ovom vremenu negativnog uticaja COVID-19 virusa priroda nas je na veoma grub način upozorila da u svom tehnološkom i ekonomskom razvoju nismo adekvatno pripremljeni na zaštitu svog zdravlja, radne i životne sredine. Otuda i da je neophodno da razvijamo i primenjujemo elemente ove zaštite. Da to činimo koristeći znanja brojnih naučnih disciplina, kao i interaktivni pristup kroz bioinženjering, putem kojih ćemo omogućiti valjano korišćenje prostora, sirovina i privrednih procesa a da nam životna sredina bude valjana za sadašnje i buduće generacije. Ovaj pristup mora biti višeslojan. Neophodno je da startuje na pravno-teorijskom nivou a da se razvija na dva nivoa: međunarodnog javnog prava i njegovog segmenta, međunarodnog ekološkog prava, ali i na nivou nacionalnih pravnih pristupa, u aktuelnom vremenu u brojnim državama baziranih na ustavnim rešenjima a razrađivanim kroz legislature. I to legislature koje neka od ovih pitanja tretiraju uopšteno ali potom i kroz specijalizovane zakonske i podzakonske tekstove tome ciljno namenjene. Otuda je cilj našeg rada da, kao ekspert UN ali i Republike Srbije, ukažem na ono što jeste primenljivo ali i na moguće propuste (praznine) na ovom polju, posmatrajući i nacionalno zakonodavstvo.
\end{abstract}

Ključne reči: biotehnološki inženjering, zaštita životne sredine, pravni pristup.

\begin{abstract}
This paper is dedicated to understanding, from the point of view of law, the impact of biotechnological engineering, both positive and negative. In this time of the negative impact of the COVID-19 virus, nature has warned us in a very rude way that in our technological and economic development we are not adequately prepared to protect our health, work and environment. Hence, it is necessary to develop and apply the elements of this protection. To do that using the knowledge of numerous scientific disciplines, as well as an interactive approach through bioengineering, through which we will enable the proper use of space, raw materials and economic processes, and that our environment will be valid for present and future generations. This approach must be multi-layered. It is necessary to start at the legal-theoretical level and to develop at two levels: international public law and its segment, international environmental law, but also at the level of national legal approaches, in the current time in many countries based on constitutional solutions and developed through legislation. And the legislatures that treat some of these issues in general, but then through specialized laws and bylaws intended for that purpose. Therefore, the goal of our work is, as an expert of the UN and the Republic of Serbia, to point out what is applicable, but also about possible omissions (gaps) in this field, observing the national legislation.
\end{abstract}

Keywords: biotechnological engineering, environmental protection, legal approach. 


\section{UVOD / INTRODUCTION}

Rad je posvećen sagledavanju mogućeg pozitivnog i negativnog uticaja biotehnološkog inženjeringa iz ugla prava u cilju zaštite zdravlja ljudi i ekosistema. Cilj našeg rada je da ukažemo na ono što na domaćem prostoru jeste primenljivo, ali i na moguće praznine na ovom polju. Pri tom mi u svom radu pažnju ponajviše usmerili unutar sedam glavnih područija: poljoprivredne proizvodnje, prehrambene industrije, rudarstva, farmaceutske industrije, energetike, tretmana otpada, te bioremedijacije, ali i onim elementima koji su takođe od značaja i za očuvanje poželjnih bioloških parametara životne sredine.

\section{METODOLOGIJA / METHODOLOGY}

Pristupajući razmatranju pitanja biotehnološkog inženjeringa i zaštite životne sredine ista posmatramo kao razvojno-promenljivu, koristeći metode pravnih nauka, a takođe metode analize i sinteze (Joldžić, 2020). Pri tom je naš pristup višeslojan. Startujemo na pravno-teorijskom nivou te prelazimo na nivo međunarodnog javnog prava a potom i nacionalne legislative, počev od ustavnih rešenja. Legislature koje ova pitanja tretiraju ne samo uopšteno već potom i kroz ciljno namenjene a specijalizovane zakonske i podzakonske akte razmatraju komparativnom analizom na nivou Međunarodnog prava i Nacionalnog zakonodavstva.

\section{REZULTATI I DISKUSIJA / RESULTS AND DISCUSSION}

\subsection{Pristup biotehnološkom inženjeringu na nivou međunarodnog prava u cilju zaštite životne sredine / Access to biotechnological engineering at the level of international law in order to protect the environment}

U cilju zaštite životne sredine i ljudskog zdravlja neophodno je da se formiraju adekvatni pravni elementi međunarodnog javnog prava, a potom i prava suverenih država. Najopštiji, za ovo značajan, dokument je Univerzalna deklaracija o ljudskim pravima (The Universal Declaration of Human Rights, 1948), koja, članom 1, propisuje da su svi ljudi jednaki u pravima i odgovornostima povezanim sa zaštitom životne sredine. Ljudi moraju da budu posmatrani bez ikakvih razlika (čl. 2), sa jasno propisanim pravom na sigurnost (čl. 3) i jednakim pravom na zaštitu pred zakonom (čl. 7), što znači i domaćim (čl. 8). Otuda i na društvenu sigurnost izgrađeni kroz nacionalne napore i međunarodnu saradnju (čl. 22). Pri tom je jasno propisano da se ništa iz Deklaracije ne može da interpretira na način koji dovodi do povrede bilo kog prava i sloboda ljudi (čl. 30). Pa tako ni opasnosti i/ili posledica biotehnološkog inženjeringa.
Značajan je i Ugovor o Antartiku (The Antarctic Treaty, 1959) koji je je zabranio svaku vojnu primenu dotičnih prostora za bilo koju vojnu primenu (čl.1, st. 1), uključujući i testiranje oružja, a posebno je zabranjeni su eksperimenti sa nuklearnim oružjem (čl. 5, st. 1). Pri tom je uspostavljena i kontrola te zabrana mogućih zagađenja od naučnih i drugih instalacija te transporta na Antartiku (čl. 7, st. 3).

Za našu temu je značajan i Međunarodni pakt o ekonomskim, socijalnim i kulturnim pravima (1966) koji jasno propisuje da svi narodi mogu raspolagati svojim prirodnim bogatstvom (čl.1, st. 2), poštujući pricip uzajamne koristi i pravila međunarodnog prava, pri čemu su države u obavezi da poštuju ova prava i to u skladu sa poveljom Ujedinjenih nacija (čl. 1, st. 3). Države su isto tako i u obavezi da poboljšavaju sve aspekte ekološke higijene [čl. 12, st. 1 pod (b)], znači i one koja zavisi od biotehnološkog inženjeringa.

Pored napred navedenih a najopštijih legislativnih elemenata međunarodnog javnog prava koji su od značaja i za pitanja povezana sa biotehnološkim inženjeringom našu pažnju privlači i jedan broj legislativnih akata i njihovih normi koji su uže predmetno orijentisani. Pa tako Konvencija o biološkoj raznovrsnosti (Convention on biological diversity, 1992) jasno propisuje da je njen cilj „očuvanje biološke raznovrsnosti, održiva upotreba njenih komponenata i pravična podela koristi koja proizlazi iz korišćenja genetskih resursa uključujući i odgovarajući pristup genetskim resursima (čl. 1)“. i to (po osnovu čl. 3) uz suvereno pravo država. U skladu sa Poveljom Ujedinjenih nacija i principima međunarodnog prava, treba koristiti sopstvene resurse, ali tako da ne dolazi do štete životnoj sredinu van svojih granica i na prostorima drugih država. Pri tom su države u obavezi održivog korišćenja i održavanja biološke raznovrsnosti (čl. 6). Otuda je svaka država Strana takođe u obavezi i da usvoji „mere koje se odnose na upotrebu bioloških resursa kako bi se izbegli ili sveli na minimum štetni uticaji na biološku raznovrsnost [čl. 10, pod (b)]", ali i postupke neophodne da bi se sprečili negativni efekti po biodiverzitet izazvani kakvim projektom [čl. 14, st. 1, pod (a)]. A da bi se to ostvarili Konvencija propisuje da pristup prirodnim resursima, uključujući genetske, reguliše zakonodavstvom (čl. 15, st. 1).

Konvenciju o biološkoj raznovrsnosti prati i tzv. Kartagena protokol o biološkoj raznovrsnosti (Cartagena Protocol, 2000) usmeren na obezbeđivanje „adekvatnog stepena zaštite u oblasti bezbednog transfera, upravljanja i korišćenja modifikovanih živih organizama stvorenih modernom biotehnologijom, koji mogu da imaju štetne posledice po očuvanje i održivost korišćenja biološke raznovrsnosti, uzima- 
jući takođe u obzir rizike po ljudsko zdravlje (čl. 1)". Otuda se članice obavezuju i na upotrebu, što podrazumeva i formiranje, odgovarajućih pravnih mera tome namenjenih (čl. 1, st. 1). Dotični Protokol „se primenjuje na prekogranični promet, tranzit, upravljanje i korišćenje svih modifikovanih živih organizama koji mogu da imaju negativno dejstvo na očuvanje i održivo korišćenje biološke raznovrsnosti, uzimajući takođe u obzir rizike po ljudsko zdravlje (čl. 14 )", ali upravljajući na način da se sprečava štetno dejstvo modifikovanih živih organizama (čl. 16, st. 2). Otuda su države Strane u obavezi da usvoje odgovarajuće unutrašnje, uključujući i pravne, mere neophodne za sprečavanje ali i kažnjavanje prekograničnog prometa modifikovanih živih organizama učinjenog protivno propisima dotične države (čl. 25, st. 1).

\subsection{Pristup biotehnološkom inženjeringu na nivou nacionalnog zakonodavstva / \\ Access to biotechnological engineering at the level of national legislation}

Osnov pravne regulative Republike Srbije od značaja za odnos spram biotehnologije korišćene na takav način da ne ugrozi ili povredi pravo čoveka na adekvatnu životnu sredinu formiran je unutar većeg broja elemenata njenog Ustava (Ustav Republike Srbije, 2006). Pojedini od njih su važni za inkorporiranje produkata međunarodnog prava, naročito javnog, pa tako i onih koje smo već ukratko objasnili unutar ovog teksta, dok niz drugih predstavlja normativni osnov, ali i smernice, za formiranje domaćih zakonskih i podzakonskih propisa usmerenih na adekvatnu zaštitu prava čoveka na zdravu životnu sredinu, kao i zaštitu nje same. Ukoliko pažnju usmerimo ka međunarodnom javnom pravu valja nam da u ovoj orijentciji imamo u vidu član 16, kao i član 194, stav 4, Ustava Republike Srbije, jer je ovim normama jasno rečeno da je svaki dokument međunarodnog prava legislativnog tipa, koji je ratifikovan, deo aktuelnog zakonodavstva naše Države, a da to jesu i opšte prihvaćena pravila međunarodnog prava.

Za našu temu je od značaja i činjenica da Ustav Republike Srbije propisuje da svako ima pravo na zdravu životnu sredinu (čl. 74, st. 1), ali i obavezu na njeno očuvanje (čl. 74 , st 3 ), kao i da podleže odgovornosti za njenu zaštitu (čl. 74, st. 2). Pri tom Zakonodavac (članom 87, st.1. Ustava) jasno kaže da su dobra od opšteg interesa u državnoj svojini. Šta više Ustav, članom 97, unutar više njegovoh elemenata, doprinosi regulaciji zaštite ekoloških vrednosti, kao i formiranju i funkcionisanju za to neophodnih sistema, pa tako pod stavom:

9. jasno propisuje da Republika, preko svojih organa, uređuje i obezbeđuje: održivi razvoj, sistem zaštite i unapređenja životne sredine; kao i zaštitu i unapređivanje biljnog i životinjskog sveta;

12. propisuje obavezu Republike Srbije da uspostavi organizaciju i korišćenje prostora - što neosporno znači i kada je ova organizacija i korišćenje neophodna za adekvatan tretman i zaštitu životne sredine, pa i od moguće negativnih biotehnoloških delovanja; te

16. obezbeđuje organizaciju, nadležnost i rad republičkih organa, pa tako i onih kojima je osnovni zadatak zaštita elemenata životne sredine.

Za nas je interesantan i član 99. Ustava koji stavom 7. jasno propisuje da se osnovna pravna pitanja regulišu zakonima, što znači i ona koja se tiču zaštite životne sredine, pa tako i od mogućih negativnih biotehnogenih uticaja, dok član 195, stavom 1, decidno propisuje da svi podzakonski opšti akti moraju biti u skladu sa zakonom, dakle i oni koji se odnose na objekt izučavanja unutar našeg teksta.

Imajući sve do sada rečeno u tekstu, a pristupajući, sa pravne strane, biotehnološkom inženjeringu, to u ovom delu rada činimo sa osnovnom idejom da elemente zaštite životne sredine, ali otuda i zdravlja ljudi, valja posmatrati u cilju očuvanja od mogućih negativnih efekata biotehnološkog inženjeringa po: poljoprivrednu proizvodnju, proizvodnju prehrambenih proizvoda, rudarstvo, industriju (uključujući i farmaceutsku), energetiku, ali i tretmana otpada, razume se i uz mogućnost za ove svrhe primerene bioremedijacije, one koja neće proizvoditi ekološki i/ili humano neželjene efekte. Obzirom na ograničenost prostora dozvolite nam da ova pitanja objasnimo kroz analizu manjeg broja elemenata:

Poljoprivredna proizvodnja, ali i proizvodnja hrane, se smatraju se najstarijim, ali i sada najprisutnijim oblikom bioremedijacije. Ali ono što se često zaboravlja jeste i potreba menjanja, sa vremena na vreme, različitih biljaka a da bi se očuvao kvalitet zemljišta. lako veštačko đubrivo jeste neophodno takođe je potrebno da se koriste i ona prirodna, takozvana stajska đubriva, a koja pozitivno, upravo putem bioremedijacije, doprinose ovom očuvanju. Ali, naglašavamo, ova đubriva ne smeju da se koriste na takav način i u takvim količinama da izazovu neželjene promene zaštićenih površina i dobara. Pa tako čl. 22. Zakona o zaštiti životne sredine (2004-2018) obavezuje na zaštitu zemljišta od degradacije uopšte, otuda i od nepropisnog upotrebljavanje mineralnog ali i organskog đubriva. A da bi se sprečila negativna dejstva po ekološke vrednosti, pa tako i zemljište, članom 70 , st. 1 , jasno je uspostavljena obaveza praćenja svih indikataora negativnih dejstava na životnu sredinu, pri čemu je stavom 2. propisano da propisano da Vlada donosi programe monitoringa. 
Kada govorimo o poljoprivrednoj proizvodnji i zaštiti od mogućih negativnih bitehnoloških uticaja pažnju valja obratiti i na Zakon o zaštiti zemljišta (2015), kojim se uređuju brojna i za našu temu značajna pitanja. Na primer član 3. propisuje obavezu zaštite zemljišta između ostalog i od: smanjenja sadržaja organske materije u zemljištu, zakiseljavanja (acidifikacije), zaslanjivanja (salinizacije) i alkalizacije zemljišta, ali i zagađenja, a sve ovo može biti produkt i negativnog biotehnogenog uticaja. Pri tom čl. 18, između ostalog, propisuje obavezu: sprečavanja ispuštanja otpadnih voda (koje mogu biti i biološki zagađene) na površinu zemljišta i u zemljište, sprečavanja smanjenja nivoa organskih materija u zemljištu u odnosu na nivo prirodnog sadržaja, sprečavanja neadekvatnog korišćenja organskih đubriva, sprečavanja neadekvatne sadnje drveća koja ne odgovaraju staništu. A ukoliko dođe do zagađivanja tada je obaveza (po osnovu Čl. 22.Sanacija, remedijacija i rekultivacija) da se degradirano zemljište rekultiviše, što je moguće i adekvatnim biotehnogenim merama.

Za adekvatan odnos spram poljoprivredne proizvodnje od značaja je i Zakon o poljoprivrednom zemljištu (2006-2017) koji takođe (članom 55) uspostavlja obavezu rekultivacije poljoprivrednog zemljišta po odobrenom projektu tehničke i biološke rekultivacije. A samo odobrenje, pa tako i biološke rekultivacije, daje nadležno ministartsvo (čl, 24, st. 1, t. 4).

Pored poljoprivredne proizvodnje, koja može da se istovremeno iskaže i kao direktna proizvodnja prehrambenih proizvoda, valja na umu imati i elemente proizvodnje hrane. Pri tom, ako razmišljamo o radu klanica jasno je zabranjeno da se iz njih ispušta otpadna neprečišćena, naročito takozvana krvava voda.

Razmišljajući o elementima i osnovima izbegavanja negativnog uticaja biotehnološkog inženjeringa pažnju valja usmeriti i na rad farmaceutske industrije te tretman otpada. Osnovne tome namenjene odredbe locirane su unutar Zakona o zaštiti životne sredine, koji jasno propisuje (članom 5, stavom 2) da su pravna lica dužna da u obavljanju svojih delatnosti obezbede primenu propisa, što podrazumeva i preduzimanje mera zaštite životne sredine. Takođe i da su u obavezi da poštuju pravila kontrole korišćenja i zaštite prirodnih resursa. Obzirom da farmaceutska industrija koristi vode u obavezi je da poštuje čl. 14, st. $1, \mathrm{t}$ :

2. - koja norma uspostavlja obavezu primene standarda, normativa i propisa o koriđenju resursa,

5. - koja se odnosi na integrisano sprečavanje i kontrolu zagađivanja životne sredine,
6. - koja se odnosi na usklađeni system dozvola, odobrenja i saglasnosti, ali i

8. - koja uspostavlja obavezu organizovanog monitoring.

Razume se, subjekti pripadnici farmaceutske industrije nemaju pravo da koriste prirodne resurse (u praksi pre svega vode) bez prethodno pribavljenog odobrenja nadležnog organa putem Saglasnosti za korišćenje - čl. 15, a u saglasnosti sa odredbama Čl. 19. - Korišćenje prostora. Pri tom su tokom svog funcionisanja subjekti pripadnici farmaceutske industrije u obavezi da ispoštuju pravila zaštite: tla i zemljišta (čl. 22), voda (čl. 23), vazduha (čl. 24), ali i očuvanja biosfere i biodiverziteta (čl. 26). te flore i faune, inače sirovina za deo svoje proizvodnje (čl. 27 ), to jest da svojom proizvodnjom ove ekološke vrednosti ne povrede. Pri tom valja imati na umu da masu svojih proizvoda ova industrija stvara upravo putem bioinženjeringa. I to ne samo insulin i antibiotike. A takođe i da ovakvu proizvodnju prati produkcija nusproizvoda ali i otpada, a koje materije mogu biti ne samo opasne već da poseduju i biloške karakteristike. Otuda valja imati na umu da Zakon o zaštiti životne sredine posebno obavezuje na postupanje sa opasnim materijama na "način kojim se obezbeđuje smanjenje rizika od njihovih opasnih svojstava po životnu sredinu i zdravlje ljudi i to u procesu proizvodnje, skladištenja, korišćenja i odlaganja (Članom 29. - Opasne materije, st. 1)".

Ukoliko se pristupa planiranju i izgradnji objekta farmaceutske industrije moraju da se ispoštuju norme Zakona o zaštiti životne sredine koje ovo regulišu, pa tako i one koje zahtevaju da se preciziraju mere zaštite životne sredine prilikom izgranje industrijskog objekta (Čl. 33. - Preventivne mere, st. 1, t. 5, ali i Čl. 34. - Prostorno i urbanističko planiranje, st. 1, t.: $2 \mathrm{~b}$ i 3) ali i izvrši strateška procena uticaja željenog farmacetskog industrijskog objekta (u skladu sa ovbavezom iz čl. 35, posebno st. 1), odnosno procena uticaja željene rekonstrukcije ili promene tehnologije postojećeg objekta (čl. 36). Pri tom svaki od objekata farmaceutske industrije može da legalno funkcioniše tek ukoliko dobije integrisanu dozvolu (u skladu sa Čl. 37. - Integrisano sprečavanje i kontrola zagađivanja). Uslovi za dobijanja ove dozvole uređuju se posebnim zakonom (čl. 37, st. 2), te pratećim propisima, pre svega: Zakonom o lekovima i medicinskim sredstvima (2010), Pravilnikom o uslovima za proizvodnju lekova, sadržaju obrasca dozvole za proizvodnju leka i Registru izdatih dozvola za proizvodnju lekova (2012), Pravilnikom o načinu kontrole kvaliteta lekova i medicinskih sredstava (2011), te Smernicama dobre proizvođačke prakse (2008). 
A kako rad industrije, što znači i farmaceutske, proivodi i različite vrste otpada to su pravna lica subjekti farmaceutske industrije u obavezi da ispoštuju i generalne odrednice Čl. 30. - Upravljanje otpadom Zakona o zaštiti životne sredine (20042018), koji obavezuje na postupanje po propisanim uslovima i merama postupanja sa otpadima. Ove uslove i mere definiše specijalizovan zakonski tekst: Zakon o upravljanju otpadom (2009-2018), koji prate i odgovarajući podzakonski tekstovi. Zakon o upravljanju otpadom uređuje niz bitnih pitanja koja su istovremeno od značaja i za regulisanje rada farmaceutske industrije, ali i sprečavanje njenih ekološki negativnih tehnogenog uticaja, samim tim što (po osnovu čl. 1, st. 1) uređuje pitanja od značaja za: vrste i klasifikaciju otpada, planiranje upravljanja otpadom i organizovanje ovog upravljanja, ali i upravljanje posebnim tokovima otpada. Sve ovo u cilju obezbeđivanja uslova za upravljanje otpadima na načine kojima se ne ugrožavaju zdravlje ljudi i životnu sredinu (čl. 2, st. 1, t. 1) ali i otklanjaju opasnosti od njegovog štetnog dejstva po zdravlje ljudi i životnu sredinu (čl. 2, st. 1, t. 3). Inače, po osnovu člana 5. ovog zakona, otpad, pa tako i farmaceutski, može biti neorganski ali i organski (biološki). Proizvodnju ovog otpada mora da prati, ali i da joj prethodi, formiranje Plana upravljanja otpadom u postrojenjima za koje se izdaje integrisana dozvola (čl. 15, st.. 1, t: 1-6), koja naročito mora da sadrži: dokumentaciju o otpadu koji nastaje u procesu rada postrojenja, kao i o otpadu čije iskorišćenje vrši operater tog postrojenja ili čije odlaganje vrši operater (vrste, sastav i količine otpada); mere koje se preduzimaju u cilju smanjenja proizvodnje otpada, posebno opasnog otpada; postupke i načine razdvajanja različitih vrsta otpada, posebno opasnog i otpada koji će se ponovo koristiti, radi smanjenja količine otpada za odlaganje; način skladištenja, tretmana odnosno ponovnog iskorišćenja i odlaganja otpada; ali i mere zaštite životne sredine i zdravlja ljudi. Dotični plan se obavezno prilaže uz Zahtev za izdavanje integrisane dozvole (čl. 15, st. 2. Zakona o upravljanju otpadom). Sam fizičkohemijski tretman farmaceutskog otpada, pa tako i onog biološkog, može biti izveden kao: neutralizacija, mineralizacija, solidifikacija, oksidacija, redukcija, jonska izmena, ali i drugim fizičko-hemijskim i/ili hemijskim procesima putem kojih se smanjuju njegove opasne karakteristike (čl. 39, st. 1). Farmaceutska fabrika ovo može da obavlja samo ako prethodno pribavi za to potrebne dozvole i deluje u skladu sa njenim parametrima (vidi Čl. 64. - Sadržaj dozvole). Pri tom se opasan otpad sakuplja, razvrstava, pakuje, obeležava i skladišti u skladu sa međunarodno harmonizovanim standardima (čl. 44, st. 5) ali i važećim pravilnikom Republike Srbije (Pravilnik o kategorijama, ispitivanju i klasifikaciji otpada, 2010), a sam tretman obavlja se na način i pod uslovima kojima se obezbeđuju životna sredina i zdravlje ljudi (čl. 44, st. 1).

Za nas je takođe značajan i odnos spram mogućeg biološki negativnog uticaja medicinskog otpada iz zdravstvenih ustanova. Odnos koji je u osnovi regulisan Zakonom o upravljanju otpadom (2009-2018), njegovim članovima 56. i 56a. Pa tako:

- proizvođač medicinskog otpada je u obavezi da sačini plan upravljanja medicinskim otpadom (čl. 56, st. 1);

- otpad iz objekata u kojima se obavlja zdravstvena zaštita obavezno se razvrstava na mestu nastanka na opasan i neopasan i odlaže u odgovarajuću ambalažu (čl. 56, st. $5)$;

- medicinski otpad se transportuje specijalnim vozilima za transport medicinskog otpada do operatera postrojenja za tretman medicinskog otpada, u skladu sa propisima (čl. 56, st. 6);

- opasan otpad iz objekata u kojima se obavlja zdravstvena zaštita uključuje infektivni, patološki, hemijski, toksični ili farmaceutski otpad, kao i citotoksične lekove, oštre instrumente i drugi opasan otpad (čl. 5, st. 13a); te

- medicinski otpad se izvozi ukoliko u Republici Srbiji nema tehničkih mogućnosti za njegovo ponovno koriščenje i /ili odlaganje (čl. 56, st. 15).

Precizna pravila za izvršavanje svih napred pobrojanih obaveza propisana su Pravilnikom o upravljanju medicinskim otpadom (2010). Pri tom sama tehnika trertmana ovog otpada može biti iskazana kroz primenu hemiklaija, toplote ali i bioloških sredstava, a što se tokom vremena razvija i mora da odgovara takozvanoj dobroj praksi.

Govoreći o biotehnološkom inženjeringu ukazujemo i na značaj pravnog pristupa biocidima. Prema zakonodavstvu brojnih evropskih država u biocide spadaju ne samo hemijske supstance već i mikroorganizmi koji mogu da unište, učine bezopasnim, ili pak odvrate od nekog prostora, nepoželjne organizme. Drugim rečima, u biocide ne spadaju samo hemijske materije već i takozvani antimikrobici, što obuhvata: gerbicide, antibiotike, antivirusne, antimikotične, antiprotozoalne i antiparazitske preparate. Inače samo određivanje svrhe biocida uočljivo je i unutar Zakona o biocidnim proizvodima Republike Srbije (vidi bliže član 2, stav 1, tačku 2. Zakona o biocidnim proizvodima).

Prema normama Zakona o biocidnim proizvodima isti mora da se koristi na takav način da se njime ne prouzrokuje štetno dejstvo po zdravlje ljudi i životinja i/ili životnu sredinu, što zahteva vođenje 
računa o racionalnoj primeni kombinacije fizičkih, bioloških, hemijskih i drugih odgovarajućih mera koje bi bile primenjene protiv organizama za koje postoji takav biološki opravdan (u skladu sa stavom 1, člana 39), pri čemu je korisnik biocidnog proizvoda dužan da poštuje sve zaštitne mere za bezbednost ljudi i životinja i životne sredine u skladu sa uputstvom za upotrebu i informacijama iz bezbednosnog lista (kako propisuje stav 2. člana 39). Zbog osobina koje poseduju određeni opasni biocidni proizvodi ne mogu da se stavljaju u promet za opštu upotrebu, ali o kojima se konktretno radi određuje se posebnim podzakonskim aktom - svojevrsnim spiskom (kako je to regulisano članom 40). Imajući u vidu osobine biocidnih proizvoda (po osnovu čl. 43, st. 3) nadležno ministarstvo određuje posebnim propisima „maksimalno dozvoljene količine ostataka biocidnog proizvoda u ili na tretiranim objektima, prostorijama, predmetima, organizmima... (koje) ne smeju biti prekoračene (Član 43 , stav 2 )“.

\section{ZAKLJUČAK / CONCLUSION}

Kako Vam je iz dosadašnjeg izlaganja verovatno očito, kada govorimo o vezi između biotehnološkog inženjeringa i zaštite životne sredine, dotični inženjering jeste primenljiv, otuda i dozvoljen, ukoliko ne izaziva kakvu opasnost i/ili posledicu koja pogađa čoveka i/ili životnu sredinu. Naime sam sistem zaštite životne sredine (čl. 2. Zakona o zaštiti životne sredine) podrazumeva očuvanje prirodne ravnoteže ali i održivo upravljanje prirodnim vrednostima (čl. 2, st. 1, t. 1) uz sprečavanje, kontrolu i sanaciju svih oblika zagađenja životne sredine (čl. 2 , st. 1, t. 2), što znači i onih koji bi bili proizvedeni neadekvatnim bioinženjering pristupom koji bi proizeo neželjene efekte, pa tako i one ekološke. No to ne znači da se svaki mogući bioinženjering blokira aktuelnim zakonodavstvom Republike Srbije, već samo onaj koji bi proizveo negativne posledice. Otuda je logično da se pored legislativnih elemenata na koje smo ukazali u dosadašnjem izlaganju radi na razvoju i novih, a specijalizovanih, zakonskih tekstova, kojima bi se regulisala uže orijentisana pitanja odnosa pravnih subjekata spram životne sredine uz korišćenje bioinženjeringa, pitanja proistekla upravo iz razvoja elemenata privrede ali i ekološkog zakonodavstva Republike Srbije. Mišljenja smo da bi taj proces trebalo da bude posmatran i tretiran kao stalna razvojno-promenljiva, što i predlažemo.

\section{LITERATURA / REFERENCES}

[1] Cartagena Protocol (2000), Cartagena Protocol on Biosafety to the Convention on Biological Diversity, Montreal on 29th January 2000.
[2] Convention on biological diversity (1992), Rio de Janeiro, 5 June 1992.

[3] International Covenant on Economic, Social and Cultural Rights, (1966), Adopted and opened for signature, ratification and accession by General Assembly resolution 2200A (XXI) of 16th December 1966.

[4] Joldžić Vladan (2020), Environmental (Ecology) Law as Independent Law Science Discipline, pod: 1.7.2 Methods of Law Sciences, str. 50.-53, izdavač: IKSI, Beograd,

[5] Pravilnik o kategorijama, ispitivanju i klasifikaciji otpada, (2010), Službeni glasnik R. Srbije, br. 56/2010.g.

[6] Pravilnik o načinu kontrole kvaliteta lekova $i$ medicinskih sredstava, (2011), Službeni glasnik R. Srbije, br. 64/2011.g.

[7] Pravilnik o upravljanju medicinskim otpadom, (2010), Službeni glasnik R. Srbije, br. 78/2010.g.

[8] Pravilnik o uslovima za proizvodnju lekova, sadržaju obrasca dozvole za proizvodnju leka i Registru izdatih dozvola za proizvodnju lekova, (2012), Službeni glasnik R. Srbije, br. 18/2012 od 9.3.2012. godine.

[9] Smernice dobre proizvođačke prakse (2008), Službeni glasnik R. Srbije, br. 28/2008.g.

[10] The Antarctic Treaty, (1959), Washington on 1st December 1959.

[11] The Universal Declaration of Human Rights, (1948), United Nations General Assembly in Paris on 10 December 1948, General Assembly resolution $217 \mathrm{~A}$.

[12] Ustav Republike Srbije, (2006), Službeni glasnik R. Srbije, br. 83/2006.g.

[13] Zakon o lekovima i medicinskim sredstvima, (2010), Službeni glasnik R. Srbije, br. 30/2010.g. od 7.05.2010.g.

[14] Zakon o poljoprivrednom zemljištu (2006-2017), Službeni glasnik R. Srbije, br. 62/2006, 65/2008 dr. zakon, 41/2009, 112/2015, 80/2017, 95/- dr. zakon.

[15] Zakon o upravljanju otpadom, (2009-2018), Službeni glasnik R. Srbije, br: 36/2009, 88/2010, 14/2016. i 95/2018.g.

[16] Zakon o zaštiti zemljišta, (2015), Službeni glasnik R. Srbije, br. 112/2015.g.

[17] Zakon o zaštiti životne sredine, (2004-2018), Službeni glasnik R. Srbije, br.: 135/2004, 36/2009, 36/2009 - dr. zakon, 72/2009 - dr. zakon, 43/2011 - odluka US, 14/2016, 76/2018, 95/2018 - dr. zakon i 95/2018 - dr. Zakon. 